\title{
Uneven solidarity: the school strikes for climate in global and intergenerational perspective
}

\author{
Catherine Walker(1)
}

\begin{abstract}
Background: The school strikes for climate (henceforth, the school strikes) initiated by Greta Thunberg have brought young people's environmental concerns to the global stage. However, there is a danger of considering youth environmental concerns only through the actions of highly mobilised young people who are heavily concentrated in the urban Global North. This article revisits qualitative data collected before the school strikes to consider how 11-14-year-olds in India and England interpreted and responded to environmental hazards and degradation in their everyday lives, and connected their situated experiences to narratives of global environmental crisis. The young people occupied a range of socio-economic positions and were experiencing different degrees of vulnerability to environmental hazards.

Results: All of the research participants were concerned about the future of the planet and their immediate environments. However, for the most environmentally vulnerable participants, future- and globally-oriented environmental concerns were overpowered by more immediate concerns. Although the young people were engaged in responses to environmental concerns, they did not see themselves as acting alone but rather with others around them, often adults. Some young people expressed doubt about the extent to which they as generationally-positioned individuals could make a difference to the problems discussed. These findings in many ways anticipate the school strikes, wherein young people are taking action to call upon adults to respond to environmental problems that young people recognise are beyond their individual capacities to resolve.

Conclusion: The environmental activism of a significant minority of young people is to be applauded, however, the interest in youth activism prompted by the school strikes runs the risk of flattening global inequalities in young people's exposure to environmental hazards, access to education and global knowledge networks. There is a need to look beyond such high-profile activities to understand how young people around the world are interpreting and responding to environmental concerns as generationally-positioned individuals operating within broader regimes of power.
\end{abstract}

Keywords: Young people, Agency, Activism, Climate change, Sustainability, Environmental education, School strikes for climate

\footnotetext{
Correspondence: catherine.walker-2@manchester.ac.uk
}

The University of Manchester, Manchester, UK

(c) The Author(s). 2020 Open Access This article is licensed under a Creative Commons Attribution 4.0 International License, which permits use, sharing, adaptation, distribution and reproduction in any medium or format, as long as you give appropriate credit to the original author(s) and the source, provide a link to the Creative Commons licence, and indicate if changes were made. The images or other third party material in this article are included in the article's Creative Commons licence, unless indicated otherwise in a credit line to the material. If material is not included in the article's Creative Commons licence and your intended use is not permitted by statutory regulation or exceeds the permitted use, you will need to obtain permission directly from the copyright holder. To view a copy of this licence, visit http://creativecommons.org/licenses/by/4.0/. 


\section{Introduction}

'When I was about 8 years old I first heard about something called climate change or global warming. Apparently that was something humans had created by our way of living. I was told to turn off the lights to save energy and to recycle paper to save resources' [1].

These words come from one of the first speeches given by then 15-year-old Greta Thunberg, who, since her first School Strike for Climate outside the Swedish Parliament in August 2018, has arguably become the face of popular climate protest. Growing up in an age of heightened environmental concern, Greta is surely not alone in having been taught about environmental concerns and what she can do about them. Through global initiatives such as the United Nations Decade of Education for Sustainable Development (2005-2014), education systems around the world have been required to 'integrate the principles, values and practices of sustainable development into all aspects of education and learning' in order to promote 'behavioural changes that are necessary if environmental integrity and economic viability are to be preserved, and to ensure that present and future generations may enjoy social justice' [2].

Young people's curricular learning is buttressed by media presentations of environmental crisis, from climate-themed disaster films, to nature documentaries carrying warnings about human over-consumption, to images such as rainforests, polar bears and the earth from space. It is difficult to imagine a young person today who is not either encountering immediate environmental hazards and degradation, or learning about these through media and educational messages linking weather events and routine consumption activities to narratives of environmental crisis [3].

Nonetheless, campaigners have argued that the proliferation of environmental knowledge has not led to appropriate action by politicians and the public [4]. For young citizens - many legally unable to vote because of their age - striking from school is a means to protest political leaders' inaction on the very environmental concerns that they as students are taught about. For, in Greta's characteristically dogmatic words, 'what is the point of learning facts in the school system, when the most important facts, given by the finest science of that same school system, clearly means nothing to our politicians and our society?' [1]. Striking from school subverts the usual generational positioning of young people as learners, and disquiets societies by positioning young people in public spaces, where they are often considered 'out of place' when unaccompanied by adults [5-7].

At the time of writing (August 2019), 3489 strikes have been registered on the \#FridaysforFuture website, with another 1268 scheduled across 145 countries [8]. Although not solely as a result of climate strikes, among the most high-profile political developments accompanying the strikes is that numerous local governments - as well as national governments of the UK, Argentina, Canada, Ireland, France and Portugal - have declared a state of 'climate emergency' [9]. Whilst the strikes and their impacts raise important questions about the changing ways that young people are responding to environmental knowledge [5], it is worth remembering that the strikers are, in global terms, a minority of young people whose connection to international knowledge networks maps onto uneven global distributions of resources and power. This can be seen on the map on the \#FridaysforFuture website [8]. The majority of the 145 countries where strikes had occurred or were scheduled had recorded five strikes or fewer at the time of writing, whilst almost all of the countries with over 100 strikes registered were in the affluent Global North: the USA (522 strikes registered, including complete and scheduled strikes), Germany (503), Italy (422), Sweden (318), the UK (315), France (298), Canada (229), Spain (194), India (167), Australia (156), Belgium (144), and Mexico (104). The \#FridaysforFuture map indicates that most strikes occurred in capitals or large cities, particularly in countries with fewer strikes [8]. The uneven distribution of the strikes may also align to political structures and governance, with significantly fewer strikes in countries with more authoritarian governance regimes.

This brief review of \#FridaysforFuture data shows that young people's access to strikes is highly uneven. Moreover, whilst striking from school is a highly symbolic activity in countries where it is the norm for young people to be in school, not all young people particularly those in contexts where access to education is a privilege of their generation - have the relative luxury of being able to miss school, or even of being in school. In 2018, UNICEF estimated that 262 million primary- and secondary-age children and adolescents globally were out of school, with higher percentages for girls, those in rural areas and those with disabilities [10]. Even among young people who have engaged in the strikes, for most, striking is an occasional form of high-profile activism [11]. Thus, alongside the interest in the school strikes, there is value in considering young people's 'everyday' environmental activism: a 'phenomenological - or lived - form of activism motivated by relationships of concern and materialised through emotions and practices in private as well as public spaces' ([12], p.14). In particular, it is pertinent to consider young people's everyday activism in contexts where the effects of climate change are felt in immediate ways, and where young people and their families have been responding to climate change for some 
time, yet without the media attention galvanised by school strikes in the Global North [13].

To explore this, this article revisits qualitative data generated in 2013/14 with 11-14-year-olds as part of a research project into young people's everyday lives and environmental concerns in India and England [14, 15]. The article looks between strike data (presented above) and data collected before the strikes to draw attention to inequalities in young people's exposures to the environmental hazards and degradation that have led to the strikes, and in the possibilities and priorities for responsive action available to young people. The article argues that these inequalities should be acknowledged, not to undermine any sense of solidarity or collective agency generated by the strikes, but as a critical reflection that solidarity cannot erase, but only reach across global power and resource inequalities. Furthermore, whilst the strikes and everyday environmental activism of young people indicate young people's capabilities to imagine and lead responses to environmental concerns, this does not - and indeed cannot - take place without supportive action from adults. In sum, the article shows the value of viewing the strikes and young people's environmental concerns in intergenerational and global perspective.

Before turning to present and discuss young people's data, the article first situates these data in reviews of existing research on children and young people in environmental governance, children and young people's expressed environmental concerns, and environmental education, citizenship and agency.

\section{Background}

Children and young people in environmental governance Recent years have seen a groundswell of critical environmental scholarship observing the centrality of individuals to environmental governance for achieving sustainability [16-19]. In addition to overlooking questions of structural power, environmental governance has been criticised for treating the lifestyles of Global North (over)-consumers as a universal norm [20-22]. For example, Indian eco-feminist Vandana Shiva argues that the global does not represent the universal human interest, it represents a particular local and parochial interest which has been globalised through the scale of its reach' ([23], p. 151).

Nonetheless, across global contexts there is a 'growing interest amongst scholars, policy practitioners and NGOs in the roles that individuals can, do and should play in the distribution and maintenance of 'environmental goods', along with the amelioration of 'environmental bads" ([16], p. 58). Middlemiss elucidates the incoherence between the theoretical notion of collective action underpinning the sustainability agenda, and the individualised policies emerging from this agenda. Thus, people receive 'mixed messages', on the one hand calling them to make changes to their individual actions, yet on the other suggesting that only collective action will resolve environmental problems [19]. That young people are not ignorant of this incoherence is evident through their strike actions.

Through the rising prominence of environmental education as 'humanity's best hope and most effective means in the quest to achieve sustainable development' ([24], p.16), children and young people have come to occupy a particularly important role in environmental governance as 'agents of change', envisaged to carry pro-environmental messages into homes and use their 'pester power' to influence family members' practices $[3,15,25]$. Like environmental governance more broadly, environmental education has been criticised for being individualistic, rather than teaching learners to question the political and economic interests that drive unsustainable consumption and the unevenly distributed environmental impacts of overconsumption [5, 26, 27].

Uncritical framings of young people as 'agents of change' also allow little consideration to how children and young people as a generational group may be disadvantaged as they negotiate everyday practices in societies that are 'generationally ordered' [12, 28, 29]. This is one example of the 'un-interrogated assumptions, rationales and technologies' in environmental governance, which erode the possibilities for action by the imagined 'environmental citizen' ([16], p. 69).

\section{Children and young people's expressed environmental concerns}

Numerous action research studies have nonetheless set out to explore children and young people's capacities to act as local-level 'agents of change' in collaborative community environmental management [30-33]. These studies offer valuable insights into young people's perspectives on environmental hazards and their aspirations for their communities. For example, Bannerjee and Driskell note how in action research in an urban 'slum' in Bangalore, 'not one child asked for a park or play equipment'. Instead, children focused on practical concerns: 'tar the road, install a water tap next to each home, clear the garbage, improve the drainage' ([30], p.148).

Explorations of young people's concerns around future-oriented and relatively more abstract environmental hazards and degradation are almost non-existent in research on Global South contexts. In the UK, exploratory research into young people's environmental concerns was carried out in 2010 with two focus groups of young people considered to be 'socially disadvantaged' [34]. Using an image-based methodology where issues such as global warming, landfill sites, and plastic carrier 
bags were represented and discussed, the authors found that young people expressed concerns about local and global issues and about other species and future generations, and made suggestions for how they and others could respond [34].

In contrast, a study with older teenagers in Australia from 2011 found that teenagers minimised and distanced themselves from global environmental risks as a way of maintaining a 'quest for order' in the face of potentially catastrophic problems ([35], p. $26)$. The author notes a contrast between young people's 'sense that future large-scale catastrophes are a virtual certainty' and the positive trajectories they imagined for their own futures ([36], p.22). He also notes that teenagers spoke of the inaction of governments and businesses as a disincentive for individual action. He concludes that young people's 'two-track' thinking around how they imagine and talk about environmental problems - as well as their naming of government inaction - may help them to manage a sense of dissonance between their hopes for the future and their understanding of the gravity of environmental problems ([35], p. 23). Similarly, in two studies in Sweden, Ojala observes a correlation between children and adolescents' perceptions of the 'environmental efficacy' of government (as opposed to individual) action on climate change and a tendency to de-emphasize the climate threat [36, 37]. In a later survey of climate scepticism involving over 600 young people, Ojala observes that young people who feel powerless when it comes to influencing environmental issues [...] perhaps cope with this feeling by denying that threats such as climate change exist' ([38], p. 1139). Ojala also found a strong influence of parental views on climate change on young people's expressed scepticism ([38], p.1143).

A systematic review of research conducted in 2015 on young people's concerns and responses to climate change makes for thought-provoking reading in light of the school strikes, although the authors note the predominance of European, Australian, and US research ([39], p.530). The authors found that 'levels of scepticism about the reality of climate change seem to be lower among younger people [than the general population]' ([37], p.529). They also found that young people express 'low levels of trust' in governments, and 'dissatisfaction with the political process' ([39], p. 530), see also [4, 5]. Recommendations from the systematic review seem to anticipate young people's strikes, as, reflecting upon the lack of trust in political leaders and adults expressed by young people in the various studies, the authors conclude that 'of the potential messengers [of climate change], young people themselves would appear to offer significant promise' ([39], p.530).

\section{Environmental education, citizenship and agency}

Critical voices within environmental education have long argued that environmental education should encompass critical thinking and support young people's citizenship [5, 26, 27]. As Hayward argues, 'without political awareness, environmental education risks becoming nothing more than a new expression of "environmentality" whereby 'children are encouraged to internalise a set of rules of behaviour that justify minimal state intervention, but do not learn to think about the moral reasons for acting in any particular way' ([5], p.99, p.113). Hayward proposes a model for ecological citizenship encompassing Social agency, Environmental education, Embedded justice, Decentred deliberation and Self-transcendence (SEEDS). The goal of the SEEDS model is to support 'our collective potential as citizens to collaborate across space and time to hold decision making to account and to imagine alternative futures' ([5], p.149).

Hayward's emphasis on social agency - agency realised through collective rather than individual action and intergenerational learning in family, school and community settings ([5], p. 73) - is notable. This fits within a wider acknowledgement by childhood and youth scholars of the disjunction between often individualistic theories of children's agency and lived experiences of interdependent action and negotiation [40-43]. Reflecting on what Oswell has elsewhere described as of the 'myth of the individual child' ([41], p. 263) in the United Nations Convention on the Rights of the Child (UNCR C) [44], Nolas observes that 'children's participation rights internationally are framed within a discourse of entitlement and self-determination emphasising their capabilities, achievements and their agency' ([45], p. 157). Nolas likewise observes that children's and young people's participation in school and community-level activities sustain the 'sociological and public imagination about what activism might look like', yet eclipse the 'fluid, nuanced, ephemeral and improvised ways' in which children exercise agency in their everyday lives ([45], p.162). Popular understandings of children's participation can moreover eclipse the ways in which '[children and young people's] opportunity to participate is usually dependent on the goodwill of adults involved in the child's life' ([46], p. 13]).

In many ways, the school strikes and \#FridaysforFuture movement would seem to be an outworking of social agency, as strikes in different locations across the world are linked to a global movement. Nonetheless, whilst the global spread of the strikes is testament to the widespread environmental concern and collective action that has emerged in reaction to government inaction, the uneven global spread of the strikes (as discussed above) is an important caveat. I turn now to consider how uneven knowledge and possibilities for action were also manifest 
in research into young people's environmental concerns conducted in India and England in 2013/14.

\section{Methodology}

Research data presented below comes from a $\mathrm{PhD}$ study entitled 'Environment and children's everyday lives in India and England: experiences, understandings and practices' [14]. Amongst the core aims of the PhD study was to explore the local particularities of how 'global' environmental concerns are experienced, understood and narrated by young people in different contexts. The $\mathrm{PhD}$ was embedded in the Family lives and the environment (part of the National Centre for Research Methods research node Narratives of Varied Everyday Lives and Linked Approaches - NOVELLA) study [15], and the studies shared a research design and sample. Participants lived in London and Hyderabad, South India and rural areas in Southern England and the Southern Indian state of Andhra Pradesh. Researchers contacted families through schools, including fee-paying and non-feepaying schools to recruit a socio-economically varied sample. The sample of young people and their locations is displayed in Table 1. In total, 24 young people (12 male, 12 female; pseudonyms shown in italics in Table 1) participated in all activities in both their homes and schools. Twenty five additional young people (pseudonyms shown in plain type) took part in school discussions only.

Multi-method data collection was carried out over three home research visits and one school research visit, incorporating individual interviews with young people and caregivers, group interviews with families at home and young people in school and a range of multi-sensory activities with young people and other family members. These activities included mobile interviews, mapping and a photo elicitation activity (for further details, see [15]). Research activities were carried out in English, Telugu or Hindi depending on the language spoken in the home or school. Activities in Telugu or Hindi were interpreted in situ by Madhavi Latha, a member of the research team.

The multi-method approach was designed to generate insights into children's everyday lives, encompassing attention to both embodied and discursive processes in how children and young people interpret and narrate their environments. Additionally, children and young

Table 1 Research sample

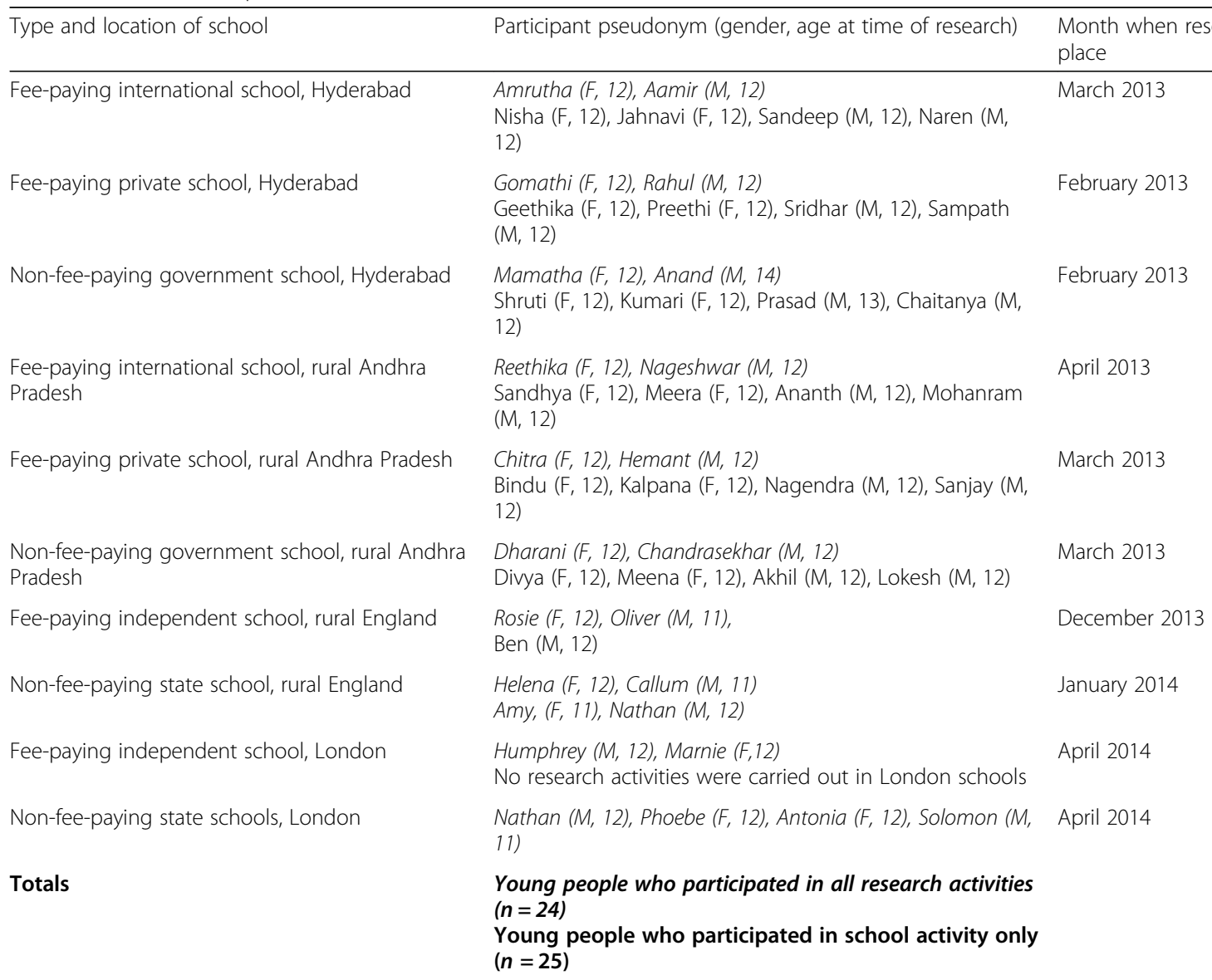


people's lives are often studied in isolation to other family members, creating a focus on children's agency that can overlook generational interdependence. Using a research design that included group interviews and activities with family members and school peers allowed for consideration of how young people's environmental concerns develop in dialogue with other key actors in their lives.

This theoretical perspective informed the narrative analytic approach employed in the study. Narrative scholars have argued that paying close attention to speakers' narratives can offer insights into the wider cultural meanings and repertoires in which such narratives are embedded and produced $[47,48]$. The analysis paid close attention to how young people interpreted and coconstructed knowledge in dialogue with those around them and in response to the varying societal norms of environmental concern prevalent in the contexts from which they spoke.

\section{Results: How young people understand, express and act upon environmental concerns}

In the sections that follow, I first consider how young people made connections between 'ordinary' consumption activities and environmental concerns, before turning to consider how some young people imagined their futures in light of their present day experiences. Following these sections, I consider how young people discussed their sense of agency as generationally-positioned individuals to act on their expressed concerns, and finally how young people disengaged from global narratives of environmental concern in their talk of localised environmental hazards or degradation. For reasons of space, only one or two narratives are selected for each section, demonstrating most clearly the phenomena at hand. I have noted for each example how prevalent this type of narrative was within the wider sample.

'It gives me goosebumps for what will happen': Connecting human consumption to global narratives of environmental concern

In Andhra Pradesh, a state-wide law banning the use of plastic bags was recalled by almost all young people in their school group discussions, often prompting explanations from young people about the harms caused by plastic. Interestingly, talk about the harms of plastic was almost non-existent in interviews and group discussions with young people in England, perhaps because the research took place before the UK media focus on plastic pollution and waste. In one group discussion in a rural private school in Andhra Pradesh, students spoke of how the plastic bag ban had helped them to realise the environmental damage caused by plastics.
Chitra: We are using plastics and then discarding them on the surface of the soil. If this remains on the surface of the earth, it seeps into the earth and [spoils the earth $=$

Hemant: $=$ They told us about this] $]^{1}$

Bindu: And due to this, there is a hole in the ozone layer.

Chitra: Teacher, it seems there are holes in the ozone layer. If we don't stop and still go on using plastics, this hole will grow in size and destroy the earth.

Bindu: It will become responsible for the destruction of the earth.

In this extract, participants weave talk of everyday human consumption (presented as universal through the use of the collective voice) with 'authoritative' environmental knowledge about the ozone layer to present an apparently inevitable narrative of global destruction. Although the scientific logic of plastics causing the hole in the ozone layer is somewhat confused, the effect of the narrative is powerful - left unchallenged, human consumption of plastic will destroy the earth.

Young people often structured their narratives of everyday concern around scientific discourses, yet they also embedded sensory reactions to phenomena encountered in their everyday lives, using their bodies as a 'communicative resource' [49]. All young people in London and Hyderabad and some young people in rural areas spoke about sensing pollution caused by vehicles with their bodies. In his individual interview in Hyderabad, Aamir spoke at length about pollution caused by vehicles, and identified this as a cause of climate change. He initially described not feeling personally affected by 'big' environmental concerns, saying: 'I kind of don't think a lot about that stuff, I am kind of in my own world. I'm happy with what I do and I don't think about others, usually'. As the interview progressed, Aamir again brought up the problem of vehicle pollution to explain his understanding of global warming, and this time related his concerns for what might happen in the future:

Aamir: And yeah, because of the pollution, the oxygen and all, it's not - the air, it's getting - it's not fresh anymore.

${ }^{1}$ The symbols [= =] indicate overlapping speech. 
Catherine: Mmm. So do you feel that that affects the things that you can do at all?

Aamir: Uh, no.

Catherine: No. So you still feel that you can go out - even if the air is polluted, it's OK, you can walk around?

Aamir: Yeah, it's like we - our bodies, it's like, used to all this stuff, right? So it's not a big deal.

\section{Catherine: $\mathrm{Mmm}$,}

Aamir: But to breathe in, uh, take the air, this might be a problem in the future, right? So ... this gives me goosebumps for what will happen in the future.

In this extract, Aamir moves from a scientific explanation of global warming to his own experience, describing the air as 'not fresh anymore'. Whilst Aamir assesses that pollution is currently manageable through the adaptive work of 'our bodies', he expresses concern over what will happen in the future, using the embodied metaphor of 'goosebumps' to express his concerns.

'I'll be living on the moon in fifteen years' time': Imagining the future in light of environmental degradation in the present

Looking further into the future, Rosie, who lived in an English village bordering a proposed industrial site, joined her parents in expressing their concern about the site. Whilst Rosie's parents' strongly narrated stance against this site was expressed in terms of intergenerational justice, Rosie herself responded imaginatively to the idea of the environment around her being destroyed and on a number of occasions, posited the idea of 'going to the moon'. This was first seen in a family discussion, as Rosie's mother spoke of the industrial site as an example of unsustainable development:

Sally [mother]: I think we're going down a road where we potentially aren't going to be able to recover [...] You know, what's the legacy we're leaving behind?

\section{David [father]: Mmm.}

Rosie: We're going to the moon apparently.

In the mobile interview, as the family stopped to look at a viewpoint near their home and discussed how the view could be destroyed if the industrial site went ahead, Rosie again brought up going to the moon, this time saying 'well, I'll be living on the moon in fifteen years' time'. This led Sally to respond 'well there you go, there's another unspoilt environment!'

In her individual interview, Rosie further elaborated on the idea of living on the moon as she imagined life for future generations:

Rosie: I mean, there's talk of going to the moon and everything, and I find that really cool, but everyone else says, like, it's not going to happen.

Catherine: Yeah.

Rosie: That's going to be cool if they can actually take it elsewhere, because that will be somewhere just to replace it. But yeah, I just find it's going to be, um something different for them [future generations]. They won't have grown up seeing all this wonderful beauty that we've seen. And um, there were probably more - years and years ago before all this technology came in and all the industrial estates were built. Um, it was probably beautiful, but I never got to see that because I wasn't around.

Rosie's twice-stated assessment of the idea of going to live on the moon as something that she finds 'cool' leads onto a more serious point in the above extract as she speaks of the moon as replacing the kind of positive aesthetic engagement with the natural environment that she argues children should have access to. This leads Rosie to reflect upon her own experience of losing access to beauty that 'probably' existed before being replaced by 'technology' and 'industrial estates'. As her parents had done previously on her behalf, Rosie uses her generational positioning to express a sense of injustice that younger generations are reaping the consequences of actions taken by older generations, over which they had no control. However, in imagining an alternative space to go to in the face of future environmental degradation, Rosie refuses a possible role for herself here as a victim. Rather, she constructs an alternative narrative framed around the possibilities for human inhabitation of the moon.

Rosie's narrative of going to the moon was unique among the research sample. Nonetheless, a number of parents of young people in both countries - as well as some young people themselves - imagined the future in the context of giving an account of how they had used resources to future generations. In rural Andhra Pradesh, Dharani's parents reported how Dharani had herself used this narrative trope when telling a story about using water responsibly:

Rani [mother]: How was the story you told us, after coming back? 
Dharani: One son comes, 'Grandpa, Grandpa, why are we taking a bath only once a week?' Then, 'people of previous generations used more, they created shortage for us. If they prevented each drop of water, had they used like this, this situation would not have come.' Grandfather told this, his grandfather.

This story, which Dharani recalled being told by a teacher at school, presents a clear causality between the resource use of one generation and the possibilities for resource use of following generations. The story is clearly intended to prompt responsive action in the present by causing the listener to imagine giving an account of their resource use to future generations. This powerful narrative trope has subsequently been used by Greta Thunberg and other climate protesters to prompt or justify their actions.

\section{'You should be telling the people who have got the big factories that': Young people's rejection of generationally- isolated responsibility}

The receptiveness of family members to environmental messages appeared to influence young people's understandings of their agency to relate messages to others within the community. Dharani recounted various 'pro-environmental' messages that she had successfully related to her family and neighbours, for example, planting trees and flowers, composting and reducing domestic water use. Although apparently confident about speaking out amongst her own family and other neighbouring families, Dharani did not present herself as individually leading the changes that her interventions may have influenced. Rather, Dharani stressed the need to recruit elder community members into 'pro-environmental' activities, as she assessed that they were overall more likely than children to listen and pass on the message to others around them:

\section{Dharani: First, elders have to start.}

\section{Madhavi: Hmm. And then?}

Dharani: And then the same, from one to another has to tell. This problem can be solved. Because if told to children, few may listen, few may not listen.

Very few young people across the sample spoke of addressing adults outside of their families with their expressed environmental concerns and where they did relate doing so, they often expressed frustration over the minimal impact of their interventions. For example, in rural Andhra Pradesh, Chitra related having plastic bags 'thrust on us', despite a recent state-wide law banning plastic bags:

Chitra: However hard we try to cut down the use of plastic, still we are not able to follow that. It keeps coming back to us in one or the other way. For example, if we go to a shop and buy some books or notes in large quantities, they are sure to pack it in huge plastic bags. However we implore them not to pack it in plastic, still it is thrust on us in one or the other form. We are not able to cut down our use.

Chitra's account shows how the seemingly straightforward act of refusing plastic bags is complicated as acting on environmental knowledge involves negotiation amidst unequal power relations. In a school group discussion carried out in rural England, Ben, Oliver and Rosie similarly highlighted their sense of relative powerlessness to be able to act on the environmental problems they spoke of:

Ben: So I think global warming, I believe it's going to happen, but -it's like 30 years, all the plants in this world will have, uh, dried up or whatever.

\section{Catherine: $\mathrm{Mmmm}$.}

Ben: And, I think -

Oliver: You can't stop -

Ben: Yeah, that's really scary but I can't do anything about it. At the moment.

In this extract, Ben demonstrates his awareness of global warming, using the example of the loss of plants over a projected period of time to communicate this. Ben's reference to not being able to do anything 'at the moment' may be a reference to his generational positioning, although he did not expand on this. This position was more directly elaborated by Rosie in the same discussion, as she spoke about renewable energy:

Rosie: We get told that we should be doing this um, renewable resources. And, well, don't tell us that. You should be telling the people who have got the big factories that, because while we're at this age, we won't be able to do anything until we're a lot older. And you're telling us this, we know this but we can't do anything about it at the moment.

Ben: Er, but I think that if you contrast that, it's kind of good to raise awareness. That actually it is happening. 
In this extract, Rosie extends Ben's assessment of the inadequacy of how they as individuals might respond to the knowledge that they receive about environmental problems 'at the moment'. However, Rosie also embeds an alternative proposal into her assessment- 'you should be telling the people who have got the big factories that'. This illustrates Rosie's assessment that action should not wait until her own generation become old enough to do something, and moreover that action needs to come from those with more power. This negotiation between Rosie and Ben again prefigures the climate strikes by showing on the one hand, young people's frustration that they cannot as individuals act sufficiently on the information they are given through environmental education, whilst on the other hand, young people's determination to raise awareness of the problems and their effects if not addressed.

'I don't know anything about that': The immediacy of the present and climate change as an absent narrative

From these now familiar narratives that in many ways prefigure the climate strikes, the article turns to consider how two young men living in rural Andhra Pradesh narrated their experiences of what might be considered by many to be 'extreme' flooding. To contextualise these narratives within the wider sample, almost all of the young people in the research in rural Andhra Pradesh, and around half of those in Hyderabad had experienced flooding that had entered or come close to their home. In England, young people had less direct experience of extreme weather, yet one participant had experienced being 'snowed in' at home and another related how a friend's roof had been damaged in a recent storm.

Hemant talked in his individual interview about a time when his family had temporarily left their home in rural Andhra Pradesh when heavy rain entered during the night. For one month, the family lived in temporary accommodation and Hemant and his brother were unable to attend school. When I asked Hemant if he was afraid of the house being flooded again, he responded negatively, explaining 'we won't be afraid because we already have an experience [of] how it will be. So we are mentally prepared to deal with it'. Like Rosie above, he declined to take up the position of victim of climate change that the interview question offered. When invited to offer an explanation for the event, Hemant focused on weather patterns in his immediate area:

Catherine: Do you have any theories about why these kinds of events like floods occur? Why that might be?

Hemant: Uh, due to the heavy rainfall, and the sudden increase in the water reaching the sea.
Catherine: The sea, ok. Ok. Is there anything else you want to say about that?

Madhavi: She is asking how the floods are occurring due to the rise of water in the sea. Do you know anything?

Hemant: Due to the heavy rainfall also recorded that month - heavy rain. And also the water also ground water rose. Like that, sea water uh, became bad, because of the water level.

Elsewhere in the interview Hemant explained the causes of 'global warming' and that he had learned about this at school, yet this was absent from his evaluation of the flood that had led his family to be evacuated. The absence of a global narrative may indicate a disconnection between the global narratives with which young people are presented in school and the actually experienced environment, where the most immediate concern is protection from local hazards.

Chandrasekhar lived in a neighbouring area to Hemant and, when he was not assisting his parents with their work as weavers, attended the local government school. Chandrasekhar and his family had spent around one month away from their home during a period of heavy rain, and had eventually moved homes, as upon return they found the flood waters had rendered their previous home uninhabitable. Although this was a particularly heavy incidence of rain, Chandrasekhar spoke of the way that his local area changed each year during the rainy season, affecting his and others' mobility.

Madhavi: We can see how this area is now. How would this surrounding area be when it rains heavily?

Chandrasekhar: The whole area turns into slushy mud. Feet would just sink into the mud if we try to walk. There will be lot of pigs roaming.

Following this explanation, we asked Chandrasekhar if he could go to school during times of heavy rain.

Chandrasekhar: I won't go to school.

Madhavi: You don't go to school at all if it rains?

Chandrasekhar: If it rains heavily we don't go. We go if the rain is lighter.

Elsewhere in research interviews, Chandrasekhar's mother explained how the family were unable to carry out their work during the rainy season, as this was 
undertaken in the road outside the home that became, in Chandrasekhar's words, 'slushy mud'. These seasonal disruptions to everyday routines were spoken of as relatively unremarkable by Chandrasekhar and his family, showing the subjectivity involved in assessing particular weather events as 'extreme'.

Although one of the worst affected, Chandrasekhar was one of only two young people in the research who claimed not to have heard of 'climate change'. The lack of resonance is seen in the following extract:

Madhavi: Have your teachers in the school told you about changes in the weather and earth getting hot or about issues like these?

Chandrasekhar: No. They never told us.

Madhavi: Did they say that there are changes in the weather?

\section{Chandrasekhar: No.}

Madhavi: Do you know the reason why the floods and heavy rains are occurring? Did you hear any one talking about them on TV or somewhere?

Chandrasekhar: No. I did not hear.

Madhavi: Do you know why these are occurring?

\section{Chandrasekhar: No.}

This disengagement from globalising explanations for changing weather patterns on the part of Chandrasekhar and Hemant illustrates the uneven use of the apparently 'global' narrative of climate change, as argued by Shiva [23]. Considering Chandrasekhar and Hemant's accounts alongside the concerns expressed by young people who were less immediately affected by weather events and environmental degradation in the present highlights the role of imagination in making the abstract narrative of 'climate change' meaningful. The future-oriented and for some - spatially distant concerns grouped within the narrative of climate change may be received with more concern by young people in relatively comfortable environments in part because of the contrast and sense of loss that the narrative of climate change evokes in the imagination (for example, Aamir's, 'goosebumps' about the future). In contrast, for young people living in contexts of seasonal weather disruptions and already existing environmental degradation, the narrative of climate change may have less resonance owing to the routine nature of adaptation to and mitigation against situated environmental hazards.

\section{Discussion}

By engaging in school strikes for climate young people around the world are engaging in arguably the most powerful form of action available to them - to miss school, the place where they are intended - among other aims - to learn to be responsible environmental citizens. The intervention of young people on their own terms of what it means to be a responsible environmental citizen has been one of the biggest and most welcome shifts in the climate movement in recent years [4]. However, the school strikes for climate are in many ways not surprising when viewed in light of young people's concerns and frustrations revealed through research carried out before the climate strikes (both presented here and reviewed in sections above).

In many ways, the discursive techniques of young people - using their bodies, their sensory experiences and their generational positioning to prompt a sense of outrage, connecting everyday consumption to farreaching global events and imagining a future without valued aspects of their present - prefigure the discursive techniques used by young people in the school strikes. Moreover, looking at how young people assess their own and others' agency to 'make a difference' to the environmental concerns they presented, and their attempts to mobilise adult family and community members, as well as political leaders in addressing these concerns speaks of their awareness of the limitations of acting as individual 'agents of change'. This awareness has now led young people to engage in strike action to call out the inaction of political leaders.

In light of data presented above, it is worth considering young people's participation in the strikes in global perspective. Youth strikers for climate are voluntarily missing school with the expressed intention of drawing public and political attention to the risks posed to humanity - and especially future generations - by climate change. Concurrently, Chandrasekhar and Hemant are among the millions of young people around the world who are missing school routinely because of reduced mobility, school closure in the event of extreme weather, or to support family livelihoods to compensate for crops and incomes lost to failed harvests or damaged properties [27, 50]. Both groups of young people could be argued to be missing school because of climate change, however the different symbolic meanings (or lack thereof) and material impacts this has for them is telling of the ways that deeply entrenched social, economic and geographical - and, of course, generational - inequalities are further exacerbated by climate change. The solidarity extended between climate strikers around the world is therefore an uneven solidarity when viewed in generational and global perspective. 


\section{Concluding remarks}

Whilst young people's environmental and political activism through the school strikes for climate is to be applauded, there is a need to look beyond these high profile activities to understand youth concerns and responses to environmental concerns. For most young people, striking is an occasional form of high-profile activism, and yet around the world, young people - including those who may not have access to an organised strike - are deeply concerned about environmental hazards and degradation and the inaction of political leaders on these concerns. Many young people are also responding to their concerns through their own everyday actions, often with family members.

This article has argued that the climate strikes are in many ways the fruition of young people's concerns, frustrations and everyday responses to climate change that have been analysed through research with young people and their families carried out prior to the climate strikes, including by the author and others referenced in this article. The article calls for greater attention to young people's responses to climate change in the context of their everyday lives, particularly in contexts outside of the Global North which have hitherto received limited media coverage in comparison to coverage of highprofile actions and addresses by Greta Thunberg and other Global North activists [13]. The article has furthermore argued for the strikes to be viewed in global and intergenerational perspective, in order to better understand the uneven solidarity that the strikes invoke. This uneven solidarity is two-fold: young people in relatively more affluent contexts hitherto less immediately impacted by climate change are striking on behalf of young people who are often worse affected, yet who may not have the same access to strikes or whose strike action may not receive the same level of media attention and political response. At the same time, parents and other adults who support the school strikes show uneven solidarity as they do so as part of a generation that has done more to cause climate change, yet which will be less adversely affected than young people over time.

An uncritical review of \#FridaysforFuture climate strike data around the world would suggest that young people in the Global North are bearing a disproportionate burden of voluntarily strikes from school. However, this must be seen in light of the burden that the most vulnerable young people carry of already living with the effects of climate change. For many young people around the world, accessing education is a priority and a luxury, often threatened by weather events and family poverty. It should be acknowledged that the idea of voluntarily forgoing education, whilst to be applauded in many contexts, would be a luxury in many others - and paradoxically, in the lives of the children and young people who are already most vulnerable to the effects of events causally linked to climate change. Thus, relatively more privileged young people who are able to strike are demonstrating an uneven solidarity.

A further danger of the school strikes is that adults think they do not need to do anything as youth are speaking out (another, more politicised, iteration of the idea of young people as 'agents of change'). Indeed, in research reviewed and presented in this paper it has been seen that even before the school strikes, many young people realised that beyond making changes in their own lives, what they really needed to do was tell adults in power to make changes, using their generational positioning to make a moral case for action. Whilst young people are still at the forefront of the strike movement, the support and solidarity of adults are intrinsic to their success. In addition to politicians and leaders, parents, teachers, neighbours and co-activists also have a role in supporting young people's actions. At the time of writing, there is an emerging \#ParentsforFuture movement, and young people have invited adults to join them for the first Global Strike for Climate in September 2019.

Once again, it must be acknowledged that this is an uneven solidarity as young people who will live for the longest with the consequences of climate change are those who have done the least to cause it. Nonetheless, the uneven nature of the solidarity should not be a barrier to intergenerational action, but rather can and should be overcome. Images of generations uniting to demand government action are promising, yet further research is needed in households, classrooms and communities around the world to consider how generations negotiate and co-envision everyday actions for a more sustainable and equitable future.

\section{Acknowledgements}

I am hugely grateful to the young people and their families who generously gave their time, energy and imagination to research presented in this paper. Many thanks to Ann Phoenix and Janet Boddy for their expert orientation of this research as PhD supervisors. Data presented in this paper were cogenerated with Madhavi Latha, Natasha Shukla and Janet Boddy. Early writing of this paper took place at the RGS-IBG Geographies of Children, Youth and Families Research Group writing retreat, and benefitted greatly from helpful and supportive conversations with other group members.

\section{Author's contributions}

This manuscript is the sole work of the author (notwithstanding individuals mentioned in acknowledgements). The author(s) read and approved the final manuscript.

\section{Authors' information}

Catherine Walker, Honorary Research Associate, Sustainable Consumption Institute, University of Manchester, UK, and Teaching Fellow in Human Geography, University of Birmingham, UK.

Funding

This research presented was funded by the Economic and Social Research Council (ESRC) National Centre for Research Methods Phase III research node funding under grant RES-576-25-0053. 


\section{Availability of data and materials}

The dataset generated and analysed during the current study are available in the UK Data Service repository, http://reshare.ukdataservice.ac.uk/852492/

\section{Ethics approval and consent to participate}

The doctoral research presented in this paper received ethical approval from the Institute of Education (now UCL Institute of Education) Doctoral School Ethics Committee. The doctoral study was also included in the ethics application submitted by the [name removed for anonymization purposes] project to the Institute of Education (now UCL Institute of Education) Faculty Research Ethics Committee.

\section{Consent for publication}

All participants in the research presented gave informed consent for their interview data to be included in anonymised form in research publications. Any quotes from interviews or personal data about research participants included in this paper have been fully anonymised in line with the UK Data Service regulations.

\section{Competing interests}

The author has no competing interests to declare.

Received: 20 August 2019 Accepted: 7 May 2020

Published online: 29 May 2020

\section{References}

1. Thunberg G. School strike for climate - save the world by changing the rules: Speech given at TEDx Stockholm; 2018. Transcript available at https:// www.fridaysforfuture.org/greta-speeches\#greta_speech_tedx. Accessed 9 Aug 2019.

2. United Nations Educational Scientific and Cultural Organisation (UNESCO), Decade of Education for Sustainable Development (DESD). No date. http:// www.unesco.org/new/en/santiago/education/education-for-sustainabledevelopment/decade-of-education-for-sustainable-development-desd/ Accessed 10 Aug 2019

3. Satchwell C. 'Carbon literacy practices': textual footprints between school and home in children's construction of knowledge about climate change. Local Environ. 2013;18:289-304.

4. Fisher DR. The broader importance of \#FridaysForFuture. Nat Clim Chang. 2019;9:428-33.

5. Hayward B. Children, citizenship and environment: nurturing a democratic imagination in a changing world. Routledge: Ashgate; 2012

6. Valentine G. Public space and the culture of childhood. London: Ashgate; 2004

7. Woolley $\mathrm{H}$. Freedom of the city: contemporary issues and policy influence on children and young people's use of public open space in England. Child Geogr. 2006:4:45-59.

8. https://fridaysforfuture.org/events/map\#. Accessed 8 Aug 2019, 17:30 GMT.

9. Climate Emergency Declaration network. Climate emergency declarations in 1,247 jurisdictions and local governments cover 798 million citizens. 2019. https://climateemergencydeclaration.org/climate-emergency-declarationscover-15-million-citizens/. Accessed 11 Dec 2019.

10. United Nations Children's Fund (UNICEF). Education annual results report 2018. 2018. https://www.unicef.org/media/55331/file. Accessed 10 Aug 2019.

11. Nolas SM, Varvantiakis C, Aruldoss V. Political activism over the lifecourse. Contemp Soc Sci. 2017;12:1-12.

12. Walker C. Embodying 'the next generation': Children's everyday environmental activism in India and England. Contemp Soc Sci. 2017;1-2: $13-26$.

13. Unigwe C. It's not just Greta Thunberg: why are we ignoring the developing world's inspiring activists? The Guardian 2019. https://www. theguardian.com/commentisfree/2019/oct/05/greta-thunberg-developingworld-activists. Accessed 11 Dec 2019.

14. Walker C. Environment and children's everyday lives: experiences, understandings and practices. Unpublished PhD thesis. London: UCL Institute of Education; 2016.

15. Phoenix A, Boddy J, Walker C, Vennam U. Environment in the lives of children and families: perspectives from India and the UK. Bristol: Polity Press; 2017.
16. Hobson K. On the making of the environmental citizen. Env Polit. 2013;22: $56-72$.

17. MacGregor S. Ecological citizenship. In: Van der Heijden HA, editor. The handbook of political citizenship and social movements. Cheltenham: Edward Elgar; 2014. p. 107-32.

18. Maniates MF. Individualization: plant a tree, buy a bike, save the world? Glob Environ Pol. 2001;1:31-52

19. Middlemiss L. Individualised or participatory? Exploring late-modern identity and sustainable development. Env Polit. 2014;23:929-46.

20. Anantharaman M. Critical sustainable consumption: a research agenda. J Environ Stud Sci. 2018:8:553-61.

21. Guha R. How much should a person consume? Environmentalism in India and the United States. Berkeley: University of California Press; 2006.

22. Mawdsley E. India's middle classes and the environment. Dev Chang. 2004; 35:79-103.

23. Shiva V. The greening of the global reach. In: Sachs W, editor. Global ecology: a new arena of political conflict. London: Zed Books; 1993. p. 14956

24. United Nations Educational Scientific and Cultural Organisation (UNESCO). Educating for a sustainable future: A transdisciplinary vision for concerted action. New York: UNESCO; 1997.

25. Uzzell D, Davallon J, Jensen BB, Gottesdiener H, Fontes P, Kofoed J, Vognsen C. Children as catalysts of environmental change. Brussels: DGXII/D-5 Research on Economic and Social Aspects of the Environment; 1994.

26. Huckle J, Wals AEJ. The UN decade of education for sustainable development: business as usual in the end. Environ Educ Res. 2015:21:491-505.

27. Manteaw B. Living on and off the environment: educating for sustainable development in an unequal world. In: Zandvliet DB, editor. Diversity in environmental education research. Rotterdam: Sense Publishers; 2009. p. 159-75.

28. Alanen L. Generational order. In: Qvortrup J, Corsaro WA, Honig MS, editors. The Palgrave handbook of childhood studies. Basingstoke: Palgrave Macmillan; 2009. p. 159-74

29. Mayall B. Towards a sociology for childhood. Maidenhead: Open University Press; 2002

30. Bannerjee K, Driskell D. Tales from truth town: Children's lives in a South Indian 'slum'. In: Chawla L, editor. Growing up in an urbanising world. Paris: UNESCO; 2002. p. 135-60.

31. Hart R. Children's participation: the theory and practice of involving young citizens in community development and environmental care. New York: UNICEF; 1997.

32. Percy-Smith B, Burns D. Exploring the role of children and young people as agents of change in sustainable community development. Local Environ. 2013:18:323-39.

33. Trott CD. Reshaping our world: collaborating with children for communitybased climate change action. Action Res. 2019;17:42-62.

34. Wilson SJ, Snell C. 'Bad for the penguins because they need ice and that to live on': an exploratory study into the environmental views, concerns and knowledge of socially disadvantaged young people. J Youth Stud. 2010;13:151-68.

35. Threadgold S. 'I reckon my life will be easy, but my kids will be buggered': ambivalence in young people's positive perceptions of individual futures and their visions of environmental collapse. J Youth Stud. 2011;15:17-32.

36. Ojala M. How do children cope with global climate change? Coping strategies, engagement, and well-being. J Environ Psychol. 2012;32:225-33.

37. Ojala M. Coping with climate change among adolescents: Implications for subjective wellbeing and environmental engagement. Sustainability. 2013;5: 2191-209.

38. Ojala M. Climate change scepticism among adolescents. J Youth Stud. 2015; 18:1135-53.

39. Corner A, Roberts O, Chiari S, Völler S, Mayrhuber ES, Mandl S, Monson K. How do young people engage with climate change? The role of knowledge, values, message framing, and trusted communicators. WIREs Clim Change. 2015;6:523-34.

40. Holloway SL, Holt L, Mills S. Questions of agency: capacity, subjectivity, spatiality and temporality. Prog Hum Geogr. 2019;43:458-77.

41. Oswell D. The agency of children: from family to global human rights. Cambridge: Cambridge University Press; 2013.

42. Richards S, Clark J, Boggis A. Ethical research with children: untold narratives and taboos. Basingstoke: Palgrave Macmillan; 2015.

43. Tisdall EKM, Punch S. Not so 'new'? Looking critically at childhood studies. Child Geogr. 2012;10:249-64. 
44. Office of the United Nations High Commissioner for Human Rights. Convention on the Rights of the Child. 1989. http://www2.ohchr.org/ english/law/crchtm. Accessed 14 Aug 2019.

45. Nolas SM. Children's participation, childhood publics and social change: a review. Child Soc. 2015;29:157-67.

46. Lansdown $\mathrm{G}$. The realisation of children's participation rights: critical reflections. In: Percy-Smith B, Thomas N, editors. A handbook of children and young people's participation: perspectives from theory and practice. Routledge: Abingdon; 2010. p. 11-23.

47. Phoenix A. Analysing narrative contexts. In: Andrews M, Squire C, Tamboukou M, editors. Doing narrative research. 2nd ed. London: Sage; 2013. p. 72-87.

48. Squire C. From experience-centred to socioculturally-oriented approaches to narrative. In: Andrews M, Squire C, Tamboukou M, editors. Doing narrative research. 2nd ed. London: Sage; 2013. p. 47-71.

49. Hyden LC. Bodies, embodiment and stories. In: Andrews M, Squire C, Tamboukou M, editors. Doing narrative research. 2nd ed. London: Sage; 2013. p. 126-41.

50. United Nations Children's Fund (UNICEF). Our climate, our children, our responsibility: The implications of climate change for the world's children. London: United Nations Children's Fund; 2008

\section{Publisher's Note}

Springer Nature remains neutral with regard to jurisdictional claims in published maps and institutional affiliations.

Ready to submit your research? Choose BMC and benefit from:

- fast, convenient online submission

- thorough peer review by experienced researchers in your field

- rapid publication on acceptance

- support for research data, including large and complex data types

- gold Open Access which fosters wider collaboration and increased citations

- maximum visibility for your research: over $100 \mathrm{M}$ website views per year

At $\mathrm{BMC}$, research is always in progress.

Learn more biomedcentral.com/submissions 